\title{
Distribution of a kokumi peptide, $\gamma$-Glu-Val-Gly, in various fermented foods and the possibility of its contribution to the sensory quality of fermented foods
}

\author{
Miyamura $\mathrm{N}^{1}$, Kuroda $\mathrm{M}^{1}$, Mizukoshi $\mathrm{T}^{2}$, Kato $\mathrm{Y}^{2}$, Yamazaki $\mathrm{J}^{2}$, Miyano $\mathrm{H}^{2}$ and Eto $\mathrm{Y}^{2}$ \\ ${ }^{1}$ Institute of Food Research \& Technologies, Ajinomoto Co., Inc., Kanagawa 210-8681, Japan \\ ${ }^{2}$ Institute for Innovation, Ajinomoto Co., Inc., 1-1 Suzuki-cho, Kawasaki-ku, Kawasaki, Kanagawa 210-8681, Japan
}

"Corresponding author: Kuroda M, Institute of Food Research \& Technologies, Ajinomoto Co., Inc., 1-1 Suzuki-cho, Kawasaki-ku, Kawasaki, Kanagawa 210-8681, Japan, E-mail: motonaka_kuroda@ajinomoto.com

Received date: Sep 30, 2015; Accepted date: Nov 02, 2015; Published date: Nov 05, 2015

Copyright: $\odot 2015$ Kuroda M, et al. This is an open-access article distributed under the terms of the Creative Commons Attribution License, which permits unrestricted use, distribution, and reproduction in any medium, provided the original author and source are credited.

\begin{abstract}
A potent kokumi peptide, $\mathrm{Y}$-glutamyl-valyl-glycine ( $\mathrm{Y}$-Glu-Val-Gly), was identified and quantified in various fermented foods using high performance liquid chromatography-tandem mass spectrometry (LC/MS/MS). This peptide was present in fermented seasoning such as fish sauces, soy sauces, and fermented shrimp pastes. Among the brewed alcoholic beverages, $y$-Glu-Val-Gly was detected in beer. In addition, the content of $y$-Glu-Val-Gly positively correlated with the quality grade of dark-colored soy sauce (correlation coefficient $\rho=0.810, p<0.05$ ). These results suggest that $\mathrm{Y}$-Glu-Val-Gly is widely distributed in fermented foods and that the content of this peptide can be an indicator of sensory quality of fermented foods.
\end{abstract}

Keywords: $\quad \gamma$-Glu-Val-Gly; $\quad \gamma$-Glutamyl-Valyl-Glycine; Kokumi; Fermented food; Fish sauce; Soy sauce; Shrimp paste; Beer; LC/MS/MS

\section{Introduction}

Recent studies have indicated that kokumi substances such as glutathione are perceived through the calcium-sensing receptor (CaSR) in humans $[1,2]$. These studies have confirmed that glutathione can activate human CaSR; and that several $\gamma$-glutamyl-peptides can also activate the CaSR; and these peptides possess the characteristics of kokumi substances; which modify the five basic tastes; especially sweet; salty and umami; when they are added to basic taste solutions or food; even though these substances have no taste themselves at the concentrations tested [1,3-8]. Among these kokumi peptides; $\gamma$-GluVal-Gly has been reported to be a potent kokumi peptide (1). In our studies; the distribution of $\gamma$-Glu-Val-Gly in various foods was investigated. Because the contents of $\gamma$-Glu-Val-Gly in foods were very low; a new method for the determination and quantification of this peptide using LC/MS/MS followed by derivatization with 6aminoquinoyl-N-hydroxysuccinimidyl-carbamate (AQC) reagent was developed [9-11] by modifying the previously reported method [12]. In the present study; the presence and quantities of $\gamma$-Glu-Val-Gly in various fermented foods is examined. In addition; possibility of the contribution of $\gamma$-Glu-Val-Gly to the sensory quality of fermented foods is also discussed.

\section{Materials and Methods}

\section{Materials}

$\gamma$-Glu-Val-Gly used in the present study was prepared by chemical synthesis as reported previously [1]. Uniformly ${ }^{15} \mathrm{~N}$-labeled L-arginine (Arg-UN) and L-proline-d7 (Pro-d7) were obtained from Isotec (Tokyo; Japan). An AccQ Fluor reagent kit was purchased from Waters (Milford; MA; USA). Other reagents are of analytical grade.
Commercial fish sauces; soy sauces; fermented shrimp pastes; and beer were purchased from the local market.

\section{Sample Preparation and Derivatization Procedure}

Samples were filtered through a $0.45-\mu \mathrm{m}$ syringe filter $(25-\mathrm{mm}$ GD/X disposable filter; Whatman PLC; Maidstone; UK). The filtrates were then passed through an Amicon Ultra Centrifugal Filter (regenerated cellulose 10,000 MWCO; Millipore; USA) at 7,500 g and $4^{\circ} \mathrm{C}$ for $15 \mathrm{~min}$. Derivatization with AQC was conducted using the AccQ Fluor reagent kit (Millipore) according to the manufacturer's protocol.

\section{Identification and Quantification of AQC-derivatized $\gamma$-Glu- Val-Gly}

Identification and quantification was conducted as reported previously $[1011,13,14]$. Separation of AQC-derivatized $\gamma$-Glu-Val-Gly was conducted by HPLC using octadecyl silica column. The peak of AQC-derivatized $\gamma$-Glu-Val-Gly was identified by the multiple reactions monitoring (MRM) method with six MRM transition channels. The combination of precursor/product ions (Q1/Q3) and the collision energies (CE (V)) were 474.2/171.2 (51V); 474.2/145.3 (30V); $474.2 / 300.3 \quad(30 \mathrm{~V}) ; 474.2 / 229.4 \quad(20 \mathrm{~V}) ; 474.2 / 304.0 \quad(20 \mathrm{~V})$ and 474.2/72.1 (50V). AQC-derivatized $\gamma$-Glu-Val-Gly in the samples was quantified by the internal standard method using the most sensitive channel (474.2/171.2; Q1/Q3). Internal standards (Arg-UN and Prod7) were monitored in the MRM transition channels at 349.0/171.1 (Q1/Q3) and 293.0/171.1 (Q1/Q3); respectively. The typical mass spectrum of AQC-derivatized $\gamma$-Glu-Val-Gly is indicated in Figure 1.

\section{Statistical Analysis}

Correlation between the $\gamma$-Glu-Val-Gly content and quality grade of soy sauce was analyzed by a Spearman's rank correlation test was performed using STAT-VIEW version 5.0 software. 
Citation: Kuroda M, Miyamura N, Mizukoshi T, Miyano H, Kouda T, Eto Y (2015) Distribution of a kokumi peptide, y-Glu-Val-Gly, in various fermented foods and the possibility of its contribution to the sensory quality of fermented foods. Fermentol Techno 4: 121. doi: $10.4172 / 2167-7972.1000121$

Page 2 of 3
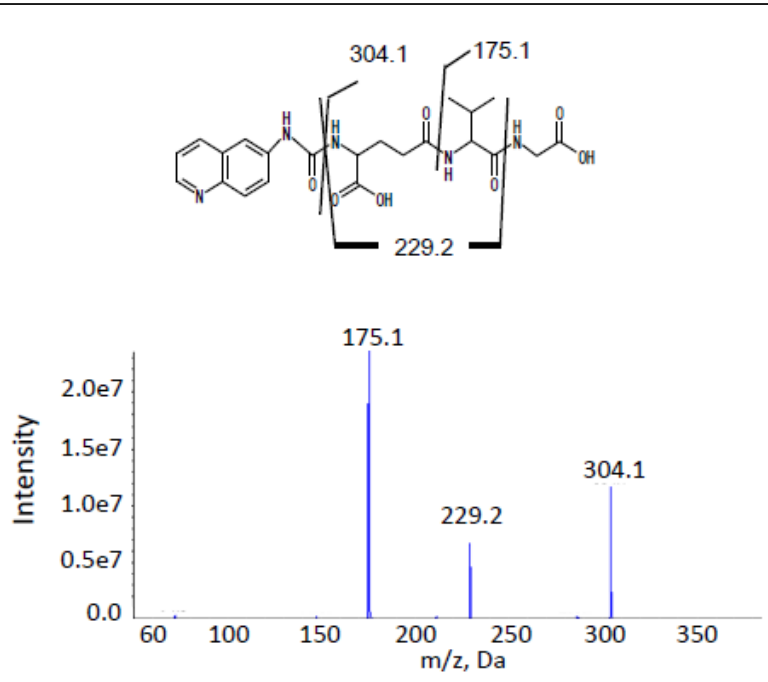

Figure 1: Typical mass spectrum obtained from the AQC-derivative of standard $\gamma$-Glu-Val-Gly. The assignment of each fragment ion is also indicated.

\section{Results and Discussion}

\section{Distribution of $\boldsymbol{\gamma}$-Glu-Val-Gly in Various Fermented Foods}

The analytical results are summarized in Table 1 . The content of this peptide in 17 brands of commercial fish sauce from Southeast Asia; East Asia and Europe was quantified. The average content in fish sauces was $4.4 \mathrm{mg} / \mathrm{L}$. The contents in Vietnamese fish sauce (Nuoc Mum) ranged from $10.4 \mathrm{mg} / \mathrm{L}$ to $12.6 \mathrm{mg} / \mathrm{L}$ and average was 11.6 $\mathrm{mg} / \mathrm{L}$; while those in Thai fish sauce (Nampra) ranged from 1.2 to 3.1 $\mathrm{mg} / \mathrm{L}$ and the average content was $2.3 \mathrm{mg} / \mathrm{L}$. Among the two Chinese fish sauce $(\mathrm{Yu}-\mathrm{lu})$, one contained $\gamma$-Glu-Val-Gly at $1.1 \mathrm{mg} / \mathrm{L}$. In addition, two of the four Japanese fish sauce contained $\gamma$-Glu-Val-Gly at 2.8 and $0.5 \mathrm{mg} / \mathrm{L}$ (average content: $0.8 \mathrm{mg} / \mathrm{L}, \mathrm{n}=4$ ). Furthermore; Italian fish sauce (Garum) contained $\gamma$-Glu-Val-Gly at $0.4 \mathrm{mg} / \mathrm{L}$. These results suggest that $\gamma$-Glu-Val-Gly is contained in various fish sauces. $\gamma$-Glu-Val-Gly was distributed in commercial Japanese soy sauces at concentrations ranging from 1.5 to $6.1 \mathrm{mg} / \mathrm{L}$ [11]; and the average content was $4.0 \mathrm{mg} / \mathrm{L}$. The contents of dark-colored soy sauce ranged from 3.1 to $6.1 \mathrm{mg} / \mathrm{L}(\mathrm{n}=6)$, while those in light-colored soy sauce ranged from 3.4 to $3.7 \mathrm{mg} / \mathrm{L}(\mathrm{n}=2)$. The content of the white soy sauce sample was $1.5 \mathrm{mg} / \mathrm{L}(\mathrm{n}=1)$. These results suggest that $\gamma$-Glu-Val-Gly is distributed in soy sauces. As shown in Table 1; commercial fermented shrimp paste condiments from Southeast Asia $(n=3)$ contained this peptide at concentrations ranging from 0.9 to $5.2 \mathrm{mg} / \mathrm{kg}$ [13]. Next, the contents of $\gamma$-Glu-Val-Gly in various brews including wine; rice wine (sake); and beer were analyzed. The analyses indicated that $\gamma$-Glu-ValGly was present in all of the beer samples $(n=8)$ at concentrations ranging from 0.08 to $0.18 \mathrm{mg} / \mathrm{L}$ [14]. In top-fermented beer $(\mathrm{n}=2)$; he content of this peptide was $0.09 \mathrm{mg} / \mathrm{L}$ and $0.11 \mathrm{mg} / \mathrm{L}$ (average content $=0.11 \mathrm{mg} / \mathrm{L})$ and the bottom-fermented beer $(\mathrm{n}=6)$ contained this peptide in the range between 0.08 and $0.15 \mathrm{mg} / \mathrm{L}$ (average content $=0.12 \mathrm{mg} / \mathrm{L}, \mathrm{n}=6$ ). However; the peptide was not detected in any of the wine or rice wine samples [14]. These results indicate that $\gamma$ Glu-Val-Gly is widely distributed in fermented foods such as fish sauces; soy sauces; fermented shrimp paste, and beer.

\begin{tabular}{|l|l|l|l|l|}
\hline Samples & $\begin{array}{l}\text { Sample } \\
\text { Size (n) }\end{array}$ & \multicolumn{3}{|l|}{ Contents of Y-Glu-Val-Gly (mg/L) } \\
\hline & & Average & Minimum & Maximum \\
\hline
\end{tabular}

Fish Sauces

\begin{tabular}{|l|l|l|l|l|}
\hline Total & 17 & 4.4 & $<\mathrm{LOQ}$ & 12.6 \\
\hline Nampra (Thailand) & 5 & 2.3 & 1.2 & 2.7 \\
\hline Nuoc Mum (Vietnam) & 5 & 11.6 & 10.4 & 12.6 \\
\hline Yu-lu (China) & 2 & 0.6 & $<\mathrm{LOQ}$ & 1.1 \\
\hline Japanese fish sauce & 4 & 0.8 & $<\mathrm{LOQ}$ & 2.8 \\
\hline Garum (Italy) & 1 & 0.4 & 0.4 & 0.4 \\
\hline
\end{tabular}

Soy sauces (Japan)

\begin{tabular}{|l|l|l|l|l|}
\hline Total & 9 & 4.0 & 1.5 & 5.3 \\
\hline Dark-colored soy sauce & 6 & 4.6 & 3.1 & 5.3 \\
\hline Light-colored soy sauce & 2 & 3.6 & 3.4 & 3.7 \\
\hline White-colored soy sauce & 1 & 1.5 & 1.5 & 1.5 \\
\hline
\end{tabular}

Fermented shrimp paste

\begin{tabular}{|l|l|l|l|l|}
\hline Total & 3 & 2.4 & 0.9 & 5.2 \\
\hline Terasi (Indonesia) & 1.0 & 5.2 & 5.2 & 5.2 \\
\hline Bagoong (Philipines) & 1 & 1.0 & 1.0 & 1.0 \\
\hline Xiajiang (China) & 1 & 0.9 & 0.9 & 0.9 \\
\hline Beer & 8 & 0.12 & 0.08 & 0.15 \\
\hline Total & 2 & 0.11 & 0.09 & 0.11 \\
\hline Top-fermented beer & \multicolumn{5}{|l|}{} \\
\hline Bottom-fermented beer & 6 & 0.12 & 0.08 & 0.15 \\
\hline LOQ: Limit of quantification &
\end{tabular}

LOQ: Limit of quantification

Table 1: The content of $\gamma$-Glu-Val-Gly in various Fermented Food

In addition, it was revealed that the contents of $\gamma$-Glu-Val-Gly in fermented seasonings such as fish sauce; soy sauce; and fermented shrimp paste were higher than those of brew such as beer. The variation of the contents would be because of the difference in the raw materials; fermentation condition and so on. However; further investigation should be performed to clarify the reasons behind the variation in $\gamma$-Glu-Val-Gly contents.

\section{Correlation between $\gamma$-Glu-Val-Gly Content and Quality Grade}

To clarify the contribution of $\gamma$-Glu-Val-Gly to the sensory quality of various fermented foods; the correlation between the content of the peptide and index of the quality of soy sauce $[11,15]$ was investigated. As shown in Table 2, Japanese dark-colored soy sauces (koikuchishoyu) are divided into three classes according to the total nitrogen content; special; higher and standard [16]. In addition; the soy sauces in the special class are divided into three grades; ultrasuper, super and ordinary. All of the six dark-colored soy sauces tested in this study are 
Citation: Kuroda M, Miyamura N, Mizukoshi T, Miyano H, Kouda T, Eto Y (2015) Distribution of a kokumi peptide, y-Glu-Val-Gly, in various fermented foods and the possibility of its contribution to the sensory quality of fermented foods. Fermentol Techno 4: 121. doi: $10.4172 / 2167-7972.1000121$

Page 3 of 3

of special class; and they consist of one ultrasuper grade; three super grades; and two ordinary grades.

\begin{tabular}{|c|c|c|c|c|}
\hline \multirow{2}{*}{$\begin{array}{l}\text { Type of soy } \\
\text { sauce }\end{array}$} & \multirow[t]{2}{*}{ Class } & \multirow[t]{2}{*}{ Grade } & \multicolumn{2}{|l|}{ Contents } \\
\hline & & & $\begin{array}{l}\text { Total } \\
\text { Nitrigen }\end{array}$ & $\begin{array}{l}\text { Dry matter of } \\
\text { extract }^{\star *}\end{array}$ \\
\hline \multirow[t]{5}{*}{ Dark-colored } & Standard & & $>1.20$ & \\
\hline & Upper & & $>1.35$ & $>14$ \\
\hline & \multirow[t]{3}{*}{ Special } & Ordinary & $>1.50$ & $>16$ \\
\hline & & Super & $>1.65$ & $>16$ \\
\hline & & Ultrasuper & $>1.80$ & $>16$ \\
\hline \multicolumn{5}{|c|}{$\begin{array}{l}\text { *:Established as Japanese Agricultural Standard (JAS) **: Dry matter except for } \\
\mathrm{NaCl}\end{array}$} \\
\hline
\end{tabular}

Table 2: Standard for Japanese soy sauces ${ }^{\star}$.

The $\gamma$-Glu-Val-Gly content in the ultrasuper grade was highest (6.1 $\mathrm{mg} / \mathrm{L}$ ); followed by the super grade (average content $=4.7 \mathrm{mg} / \mathrm{L}$ ); and the ordinary grade (average content $=3.7 \mathrm{mg} / \mathrm{L}$ ). The Spearman's rank correlation test indicated that the content of $\gamma$-Glu-Val-Gly was positively correlated with the quality grade of commercial soy sauce (correlation coefficient $\rho=0.810 ; \mathrm{p}<0.05$ ) (Figure 2).

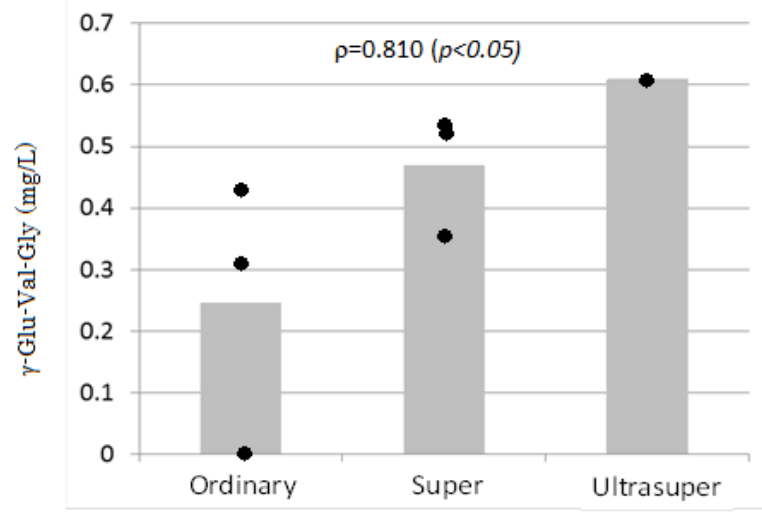

Figure 2: Correlation between the contents of $\gamma$-Glu-Val-Gly and the quality of dark-colored soy sauces. Each bar indicates the mean value; and plots indicate the contents in each sample.

These results suggest that $\gamma$-Glu-Val-Gly contributed to the sensory quality of fermented foods.

In our laboratory; the contents of $\gamma$-Glu-Val-Gly in other fermented foods and the contribution of this peptide to the quality of foods is now in progress.

\section{Conclusion}

The content of a kokumi peptide, $\gamma$-Glu-Val-Gly; in various foods was analyzed by LC/MS/MS followed by derivatization with AQC. The quantitative analysis indicated that $\gamma$-Glu-Val-Gly is distributed in various fermented foods, such as fish sauce, soy sauce, fermented shrimp paste and beer. Furthermore; the content of this peptide has been positively correlated with the quality grade of soy sauces; suggesting that $\gamma$-Glu-Val-Gly contributes to the sensory quality of fermented foods.

\section{References}

1. Ohsu T, Amino Y, Nagasaki H, Yamanaka T, Takeshita S, et al. (2010) Involvement of the calcium-sensing receptor in human taste perception. J Biol Chem 285: 1016-1022.

2. Maruyama Y, Yasuda R, Kuroda M, Eto Y (2012) Kokumi substances, enhancers of basic tastes, induce responses in calcium-sensing receptor expressing taste cells. PLoS One 7: e34489.

3. Ueda Y, Sakaguchi M, Hirayama K, Miyajima R, Kimizuka A (1990) Characteristic flavor constituents in water extract of garlic. Agric Biol Chem 54: 163-169.

4. Ueda Y, Yonemitsu M, Tsubuku T, Sakaguchi M, Miyajima R (1997) Flavor characteristics of glutathione in raw and cooked foodstuffs. Biosci Biotechnol Biochem 61: 1977-1980.

5. Dunkel A, Köster J, Hofmann T (2007) Molecular and sensory characterization of gamma-glutamyl peptides as key contributors to the kokumi taste of edible beans (Phaseolus vulgaris L.). J Agric Food Chem 55: 6712-6719.

6. Toelstede S, Dunkel A, Hofmann T (2009) A series of kokumi peptides impart the long-lasting mouthfulness of matured Gouda cheese. J Agric Food Chem 57: 1440-1448.

7. Toelstede S, Hofmann T (2009) Kokumi-active glutamyl peptides in cheeses and their biogeneration by Penicillium roquefortii. J Agric Food Chem 57: 3738-3748.

8. Nishimura T, Egusa A (2012) Classification of compounds enhancing "koku" to foods and the discovery of a novel "koku"-enhancing compound. Jpn J Taste Smell Res 19: 167-176.

9. Kuroda M, Kato Y, Yamazaki J, Kageyama N, Mizukoshi T, et al. (2012) Determination of $\gamma$-glutamyl-valyl-glycine in raw scallop and processed scallop products using high performance liquid chromatography-tandem mass spectrometry. Food Chem 134: 1640-1644.

10. Kuroda M, Kato Y, Yamazaki J, Kai Y, Mizukoshi T, et al. (2012) Determination and quantification of $\hat{\mathrm{I}}^{3}$-glutamyl-valyl-glycine in commercial fish sauces. J Agric Food Chem 60: 7291-7296.

11. Kuroda M, Kato Y, Yamazaki J, Kai Y, Mizukoshi T, et al. (2013) Determination and quantification of the kokumi peptide, $\hat{\mathrm{I}}^{3}$-glutamylvalyl-glycine, in commercial soy sauces. Food Chem 141: 823-828.

12. Armenta JM, Cortes DF, Pisciotta JM, Shuman JL, Blakeslee K, et al. (2010) Sensitive and rapid method for amino acid quantification in Malaria biological samples using AccQ-Tag ultra performance liquid chromatography-electrospray ionization-MS/MS with multiple reaction monitoring. Anal Chem 82: 548-558.

13. Miyamura N, Kuroda M, Kato Y, Yamazaki J, Mizukoshi T, et al. (2014) Determination and quantification of a kokumi peptide, $\gamma$-glutamyl-valylglycine, in fermented shrimp paste condiments. Food Sci Tech Res 20: 699-703.

14. Miyamura N, Iida Y, Kuroda M, Kato Y, Yamazaki J, et al. (2015) Determination and quantification of kokumi peptide, $\hat{\mathrm{I}}^{3}$-glutamyl-valylglycine, in brewed alcoholic beverages. J Biosci Bioeng 120: 311-314.

15. Yokotsuka T (1986) Soy sauce biochemistry. Adv Food Res 30: 195-329.

16. Yokotsuka T (1961) Aroma and flavor of Japanese soy sauce. Adv Food Res 10: 75-134. 